\title{
CUL4B wt Allele
}

National Cancer Institute

\section{Source}

National Cancer Institute. CUL4B wt Allele. NCI Thesaurus. Code C93070.

Human CUL4B wild-type allele is located in the vicinity of Xq23 and is approximately $51 \mathrm{~kb}$ in length. This allele, which encodes cullin-4B protein, is involved in the mediation of protein ubiquitination. Mutation of the gene is associated with both mental retardation, X-linked, syndromic type 15 and Cabezas syndrome. 